\title{
THE ECONOMICS OF FORESTRY IN REHABILITATION
}

\author{
By J. D. B. Harrison \\ President-elect, Canadian Society of Forest Engineers
}

T HAS been correctly said that the post-war rehabilitation period will be a time of transition from a war economy to a peace economy. Experience has shown that Canada's forests are among her chief war assets. Wooden aircraft are among the fastest in the world; wooden buildings house factories, offices and troops; munitions, fighting vehicles, guns and food are transported in wooden containers; and wood furnishes pulp for the manufacture of paper, textiles, explosives and a host of other products.

Without her marvellous forests and great forest industries Canada's war effort would be crippled, the essential needs of the United Kingdom for timber could not be met, and the demands of the United States for Canadian lumber and newsprint would remain unfilled.

When peace returns the forests will stand high among the principal sources of our national wealth. If managed wisely and protected well they will produce and continue to produce more wealth in future than they have in the past. If this duty to posterity is neglected, the coming generation will suffer.

Better forest management, including better protection against fire and pests, must be one of the chief post-war aims if Canadians are to reach the goal of universal well-being that their endowment of natural resources puts within their grasp.

It may be advantageous to review very briefly some of the reasons why our forests should play a very large part in any scheme for the rehabilitation of returned men and others seeking employment when the war is over. Of the total land area of the nine provinces, 58 per cent is occupied by forests as compared with 42 percent occupied by non-forested agricultural lands and waste and other areas. In our immense forest industries we have invested more than $\$ 1,100$ million and the net value of the products of those industries exceeds $\$ 450$ million annually. In 1940 the forests and the industries drawing raw materials from them gave work equivalent to yearround employment for 224,000 men, of whom 100,000 were engaged in woods operations. Thus the forests directly provide subsistence for well over one-half million of our people. Salaries and wages derived from forest products exceeded $\$ 240$ million annually. Among all manufacturing indus. tries sawmilling gave the most employment and pulp and paper-making stood second.

In external trade, "wood, wood products and paper", yielded a favourable balance of $\$ 310$ million in 1940 , as compared with a deficit of $\$ 199$ million from trade in all other commodities. A very large part of the 
balance from trade in wood and paper became available in United States funds and played an important part in financing our purchases of urgently needed equipment and supplies for our rapidly expanding war effort. This was particularly important in a year when, because of restrictions on the international movement of funds, our credit balances in London could not be transferred to New York.

The need for improvement work in the forest, and more particularly for improvement of facilities for forest protection, is illustrated by the fact that of our total annual depletion, 70 per cent is used and 30 per cent wasted through the action of fire and pests. It is well known that severe shortages of wood have already developed in certain localities, and the general quality of our forest crops is tending downward. Even though it is unlikely that the rate of depletion effective immediately before the war was reducing the total volume of wood in the country, it would be hazardous to plan on any considerable increase in our utilization rate until better forest management is introduced. We know that in northern Europe the permitted annual depletion is twice as high as our current rate, and our growing conditions and other factors should allow us to reach and pass the European standards.

The above factors have been mentioned to show why improvement of the forest estate ought to receive most serious consideration in plans for rehabilitation of our men. They do not in any way affect our conviction that the main object must be the welfare and re-establishment of the men themselves. It is probable that during the immediate post-war period employment may have to be found for three groups of people, namely,

\footnotetext{
1. Returned service men,

2. Former munition workers,

3. Unemployed youths.
}

These groups will have definite characteristics and each will have to be handled accordingly.

Generally speaking, returned soldiers will not want to go into the woods and submit to camp discipline in large groups. Insofar as possible woods work should be found, for those returned men who wish to engage in it, in the vicinity of their own homes. Improvement of farm woodlots, work in community and township forests and in partially denuded areas such as the Ganaraska watershed should offer suitable opportunities for employment of considerable numbers of returned soldiers, working in small groups. Here we may pause a moment to consider whether such work would be worthwhile and who would reap the benefits. Only occasionally would it be possible to make the improvement of the rural forestry situation a self-supporting proposition. But, if measures should be taken which resulted in regulating stream flow, raising the water table, improving water supply and providing plentiful local supplies of wood for local consumption, the private owners of land and the municipalities concerned would benefit to a very great degree. As easily accessible agricultural lands once more became productive the assessable land values would rise, taxes could be paid, schools could be 
reopened and roads and other municipal works could be renovated. The restoration of proper forest conditions could mean the difference between bankruptcy and a healthy financial condition for the municipality. This in turn might well lessen demands on provincial treasuries as well as enabling derelict lands to be restored to their proper function in the production of new wealth.

Considerable numbers of ex-munitions workers and youths may be glad to work in properly organized camps in the forest proper. Here experience gained in the co-operative operation of the National Forestry Program by Dominion and Provincial authorities in 1939 should be a valuable guide. Certainly one of the most important groups of projects undertaken should be the development of permanent communication systems in the forest, including roads and perhaps river improvements.

It must be borne in mind that most of the men who will be available for forest employment will be thoroughly accustomed to the use of machinery. Relief projects undertaken a decade ago placed emphasis on hand labour in order to give maximum employment through use of the limited funds available. After the war our plans should be made for the use of machinery where possible for the same reason that industrial companies use machinery, namely, ultimate economy. Some machines may be difficult to obtain but surplus army vehicles, properly reconditioned in army workshops, should be available in whatever numbers are desired.

If our efforts at reconstruction after the war are to be successful, we must reach a condition of full employment. This means that we must keep up a very high level of production, which in turn implies a high rate of industrial activity. Only through high production can we obtain the large national income which must be available if governments are to be able to obtain the funds they will need to carry out their part of the reconstruction work. Basic reliance for mass employment must rest on industry but government-sponsored projects may help specific situations temporarily. On the other hand, work provided by governments for the sake of providing work cannot be a long-term answer to the problem. From all this it follows that measures taken after the war must not unduly impede industrial activity and industry must be regarded as the chief employer.

One of the most important activities from the point of view of Canadian reconstruction must be energetic promotion of foreign trade. Canada must continue to rely heavily on external markets and this is particularly true with respect to the forest industries.

Among the purely forestry projects which ought to engage our immediate attention, the introduction of better forest protection and the completion of better forest inventories on a national scale are most important. The next step must be the establishment of regional sustained yield possibilities. These will form the basis from which the future development of forest industries will be controlled.

Industries and governments should co-operate in intensive studies of the economic significance of established forest utilization practices. Means must 
be found to use our forest products to best advantage. Some of our competitors divert individual logs to the manufacture of those end products which will yield the highest margin of profit. Canada must eventually do the same if she is to maintain her place in world markets.

Plans for reconstruction of the forest must allow for watershed protection, improvement of recreational values and establishment of conditions suitable to wildlife. The advice of experts in these fields ought to be obtained in rounding out any program of forest improvement.

Methods by which rehabilitation work in the forests for our men and improvement of the forests themselves will be financed cannot be discussed to any purpose until our governments, both Dominion and Provincial, have given an indication as to what their policy will be. In the meantime we may recall that Dr. Wallace, Chairman of the Sub-Committee on Natural Re. sources of the Committee on Reconstruction, stated to a committee of the House of Commons last summer that, "The first resource that we have given our thought to in the committee is forestry, for the reason that we feel that there is a greater possibility for the use of men and a greater need for conservation in forestry than in any other of the natural resources of Canada." $\mathrm{He}$ indicated that in his judgment the best results would be obtained through co-operation of government and private industry. He thought that corporations would be good forest conservationists from self-interest provided their conditions of tenure were such as to justify the expending of capital.

Plans for the future are now being considered. An Act already passed by the Dominion Parliament provides for re-establishment of veterans on the land. In the discussions which took place when that bill was in Committee, tentative figures of 25,000 men and $\$ 80$ million were mentioned. These figures may be considered as "targets" towards which future planning can be directed.

We need similar targets to guide our planning for forestry. It is believed that general figures for the Dominion can best be arrived at by grouping together target figures covering individual provinces and regions. The degree of recognition accorded to forestry in the final rehabilitation and reconstruction programs will largely be influenced by the plans submitted to the proper authorities for consideration. It is suggested that members of this Society should exert their influence and efforts towards furthering the preparation of adequately detailed plans for the districts, regions, and provinces in which they live and work. If regional target figures in terms of men and money can be established, the larger provincial and Dominion plans can then be built up.

\section{E. J. Zavitz}

\section{DISCUSSION}

I AM INTERESTED particularly in the human and social factors which fere stressed in the papers by Mr. Wilson and Mr. Harrison. I may say that I was on the Committee after the last war and that this became 
the largest problem. It was a simpler matter to lay out a big plan than to solve the social end of it. The Ontario Government has joined with the Federal Government in trying to draft a definite scheme. Mr. Richardson, who is in charge of this work, will no doubt be able to give you some definite information when he comes to the meeting later. The Ontario Inter-departmental committee on Post-war Rehabilitation made a proposal to Dr. James that a survey be undertaken in relation to streamflow, reforestation and agriculture. The survey was undertaken but the report is not by any means finished.

Avila Bedard

I think I shall make but one remark at this stage. I believe that forest colonies after the pattern of the collective farms developed in Russia might be similarly organized in the Province of Quebec.

\section{G. L. Miller}

Just a word only to say that in line with the other provinces, New Brunswick is now making plans for its rehabilitation program. The provincial Committee appointed by the Government is under the chairmanship of Dr. N. A. M. MacKenzie, President of the University of New Brunswick, who has Hon. J. G. Bouchard, Chairman of the New Brunswick Electric Power Commission associated with him as representative of the Government and another member representing labour. Previous to the appointment of Dr. MacKenzie's Committee, an informal committee comprised of officers of the Department of Lands and Mines and others representing forest industries met and drew up a very comprehensive and complete plan for rehabilitation which has been submitted to Dr. Mackenzie and which, I believe, will receive due consideration from his Committee. I wish to say that we in New Brunswick will complete our plans as soon as possible. Dr. MacKenzie has now had an organization meeting and all those organizations interested have been asked to submit their suggested plans as soon as possible. I think that covers the matter to-date.

\section{J. C. Veness}

I have discussed community forests several times with New Brunswick officials and it seems to me that their present methods of placing settlers on land are faulty. I may say that I do not believe the Militia should have anything to do with Forestry in Post-war Rehabilitation work.

\section{E. H. Roberts}

In connection with forest colonies in the West, we have advanced in progressive stages. From 1912 to 1920 the Dominion Forest Service carried out forest surveys throughout Northern Saskatchewan delineating proposed boundaries of forest reserves which later were largely incorporated in Dominion Forest Reserves. Subsequently the Topographical Surveys Branch conducted land classification surveys over the same and tributary lands with somewhat more attention being given to soils and waste lands that would be adaptable to agriculture. In those days, 25 or more years ago, the majority of the people were only interested in agriculture and the expansion of this industry 
to the western boundaries of the province for the growing of wheat. From five to six million acres were set aside as permanent forest reserves with irregular boundaries which were altered from year- to year regardless of whether the soil were suitable or not, due to local pressure for more settlement land. We have finally reached a stage where the Soil Survey of the province, conducted by the University, examines an area as to its suitability for agriculture and, in conjunction with the forest information available, a logical decision is made as to the location of permanent forest boundaries and the establishment of provincial forests prior to the expenditure of large sums of money on fireguards and permanent improvements. The Soil Survey has been going into the quality of the soil, its productivity and classification much more intensively than had hitherto been attempted and their reports can be relied upon to delineate essential forest areas.

The province has been investigating the possibility of useful projects for rehabilitation and development of its forests and natural resources. One example is a considerable area of forest that has been depleted by one or more fires. It has been proposed that this area be covered by a soil survey, an economic survey and then sub-divided into agricultural settlement lands, woodlots and forest blocks. It will then be possible to designate a suitable portion to a forest colony wherein homesteads may be allocated to settlers. The land can be cleared by mechanical means, buildings constructed, community pastures established, haylands developed by drainage or flooded by the con' struction of small dams to regulate water flow. Marsh lands may be developed as muskrat breeding grounds or fur farms established. The settlers may be employed during the winter months, or off season, in the adjoining forest area in timber production or forest improvement work. By careful planning and supervision, the men to be re-established in the area can be full-time employed, either on their own land or in the neighbouring forest. Thus their interest in the conservation of the forest will be stimulated as they will derive a portion of their income from this source.

\section{G. M. Dallyn}

I believe that reforestation will be one of the big things to tackle. Will we be in a position to take hold of a big reforestation scheme if the war should suddenly stop?

\section{J. C. W. Irwin}

We may find that there will not be as many men available in Ontario as some expect. I would like to know how Mr. Zavitz rates the importance of the different types of work suggested. He apparently regards it as a matter of social concern, that is, that the happiness and social wellbeing of the men is of primary concern and the work only a means to an end.

\section{E. J. Zavitz}

In answer to Mr. Dallyn's question, I would say that we haven't enough seedling stock to employ very many men. We can count on about twenty million seedlings, one-third of which would not be of species suitable for such a project. The biggest problem is seed supply. We are hoping that we 
may get better seed years for the collection of seed of some of our best species.

With regard to Mr. Irwin's question as to the relative importance of the different types of work, I believe that conservation rates first. This would include not only planting but other means of stream control, dam building, etc. As to planting itself, I would point out that the season is very short, amounting to only $2-4$ weeks in the spring and 2.4 weeks in the autumn. This means that planting will not offer year-round employment. I repeat that the main problem is a social one. Men won't live in scattered regions without social contacts.

\section{Dr. W. R. Haddow}

Two things have struck me as of special importance in what Mr. Wilson has said. The first is with respect to education and the importance of preliminary psychological tests relating to aptitudes. This is perhaps related more to rehabilitation than to the emergency of civil re-establishment. For the latter, it will be necessary to provide a cushioning period during which men will gradually find their own work which in forestry will be, in the main, in the woods operations relating to the giant manufacturing industries described by Mr. Harrison. Plans are necessary to tide over a period until the great woods industry is on a stabilized basis. 